\title{
Immunosuppressive/anti-inflammatory cytokines directly and indirectly inhibit endothelial dysfunction- a novel mechanism for maintaining vascular function
}

Ying Shao ${ }^{1}$, Zhongjian Cheng ${ }^{1}$, Xinyuan $\mathrm{Li}^{1}$, Valeria Chernaya ${ }^{1}$, Hong Wang ${ }^{1}$ and Xiao-feng Yang ${ }^{1,2^{*}}$

\begin{abstract}
Endothelial dysfunction is a pathological status of the vascular system, which can be broadly defined as an imbalance between endothelium-dependent vasoconstriction and vasodilation. Endothelial dysfunction is a key event in the progression of many pathological processes including atherosclerosis, type II diabetes and hypertension. Previous reports have demonstrated that pro-inflammatory/immunoeffector cytokines significantly promote endothelial dysfunction while numerous novel anti-inflammatory/immunosuppressive cytokines have recently been identified such as interleukin (IL)-35. However, the effects of anti-inflammatory cytokines on endothelial dysfunction have received much less attention. In this analytical review, we focus on the recent progress attained in characterizing the direct and indirect effects of anti-inflammatory/immunosuppressive cytokines in the inhibition of endothelial dysfunction. Our analyses are not only limited to the importance of endothelial dysfunction in cardiovascular disease progression, but also expand into the molecular mechanisms and pathways underlying the inhibition of endothelial dysfunction by anti-inflammatory/immunosuppressive cytokines. Our review suggests that anti-inflammatory/immunosuppressive cytokines serve as novel therapeutic targets for inhibiting endothelial dysfunction, vascular inflammation and cardio- and cerebro-vascular diseases.
\end{abstract}

Keywords: Anti-inflammatory cytokines, Endothelial dysfunction, Metabolic cardiovascular diseases

\section{Introduction}

The endothelium has long been viewed not only as a monolayer of endothelial cells (EC) lining the lumen of all blood vessels to function as a protective biocompatible barrier between tissues and circulating blood, but also as a highly specialized, heterogeneous [1], dynamic, disseminated organ [2] with paracrine and autocrine functions which respond to alterations of hemodynamic forces and chemical stimuli. In its entirety, the endothelium is composed of 1 to $6 \times 10^{13} \mathrm{EC}$ covering a surface area of more than 1,000 square meters [3,4]. Endothelial dysfunction is a systemic pathological condition, which

\footnotetext{
* Correspondence: xfyang@temple.edu
${ }^{1}$ Department of Pharmacology, Center for Metabolic Disease Research and

* Correspondence: xfyang@temple.edu
'Department of Pharmacology, Center for Metabolic Disease Research and Cardiovascular Research Center, Temple University School of Medicine, MERB 1059, 3500 North Broad Street, Philadelphia, PA 19140, USA

2Department of Microbiology and Immunology, Temple University School of Medicine, Philadelphia, PA 19140, USA
}

(c) 2014 Shao et al.; licensee BioMed Central Ltd. This is an Open Access article distributed under the terms of the Creative Commons Attribution License (http://creativecommons.org/licenses/by/4.0), which permits unrestricted use, distribution, and reproduction in any medium, provided the original work is properly credited. The Creative Commons Public Domain Dedication waiver (http://creativecommons.org/publicdomain/zero/1.0/) applies to the data made available in this article unless otherwise stated. dependent vasoconstriction and vasodilation. Endothelial dysfunction initiates a number of events that trigger EC activation, which predisposes the vessel wall to be stimulated by cardiovascular risk factors [5]. Specifically, endothelial dysfunction is associated with reduced nitric oxide (NO) production, increased reactive oxygen species (ROS) production, upregulation of cytokines and chemokines, decreased anticoagulant properties and enhanced platelet aggregation and leukocyte adherence. One related but more specific term known as endothelial activation is characterized by the upregulation of EC adhesion molecules such as intercellular adhesion molecule-1 (ICAM-1), vascular cell adhesion molecule-1 (VCAM-1) and increased secretion of cytokines and chemokines, which facilitates trans-EC migrations of monocytes, macrophages, dendritic cells, leukocytes, B cells, natural killer cells, and T cells [6]. Perturbations in EC functions play important 
roles in the development of several major diseases including cardiovascular diseases, metabolic syndrome, systemic inflammatory diseases, and sepsis [7].

Cytokines, including lymphocyte-generated lymphokines, monocyte-produced monokines, chemokines [8], interferons, interleukins, adipocyte-secreted adipokines [9] and muscle-generated myokines [10] act by binding to their specific receptors in concert with specific cytokine inhibitors and soluble cytokine receptors, to regulate innate and adaptive immune responses. They are produced by many types of cells such as vascular EC, in response to the stimulations caused by metabolite-related danger signal-associated molecular patterns (DAMPs) [11] and pathogen-associated molecular patterns (PAMPs) [12] that include bacterial endotoxins, injury, or inflammatory mediators [13]. Cytokines can be divided into pro-inflammatory and anti-inflammatory (immunosuppressive) cytokines. Anti-inflammatory cytokines may either inhibit pro-inflammatory cytokine synthesis or control proinflammatory cytokine-mediated cellular activities [14,15]. Numerous reviews have been published on the roles of pro-inflammatory cytokines on eliciting endothelial dysfunction [16-26] and many pro-inflammatory cytokine antagonists have been developed. These new cytokine anta-gonists include: a) etanercept, infliximab, adalimumab and certolizumab pegol as tumor necrosis factor- $\alpha$ (TNF- $\alpha$ ) antagonists; b) Sant1, Sant5, and Sant7 as interleukin-6 (IL-6) receptor superantagonists; c) anakinra as IL-1 receptor antagonist; d) IL-1 receptor antagonist (IL$1 \mathrm{Ra})$ as IL- $1 \alpha$ and IL- $1 \beta$ antagonists; e) IL-18BP as IL18 antagonist, and $f$ ) soluble Endoglin as transforming growth factor- $\beta$ (TGF- $\beta$ ) antagonist [27]. Potential therapeutic effects of these new inflammatory cytokine antagonists on endothelial dysfunction remain unclear. In addition, previous reports showed that anti-inflammatory cytokines IL-10, members of the TGF- $\beta$ family, and proresolving lipid mediators (such as lipoxins, resolvins, and protectins) may suppress pro-inflammatory signaling [28]. Moreover, recent studies have shown that the spectrum of anti-inflammatory cytokinesis expanding [29], which may hold promise for developing potential novel therapeutics and tools for the diagnosis and management of diseases [27]. However, the roles of anti-inflammatory cytokines in endothelial dysfunction have not been extensively analyzed. Therefore, the protective effects of anti-inflammatory cytokines against endothelial dysfunction are the focus of this review (Figure 1).

\section{Endothelium-dependent regulation of vascular tone}

Recent studies have demonstrated that endothelial dysfunction is a mechanistic link between atherosclerotic risk factors and an early development of vascular diseases, which is an independent predictor of future cardiovascular pathologies in patients with atherogenic risk factors or ischemic heart disease [30]. Although endothelial dysfunction may have a more generalized definition, current practical definition is related to the endothelial dysfunction of vascular tone. A healthy endothelium modulates vascular tone by producing numerous vascular dilators and constrictors. In clinical practices, flow-mediated dilation test is the standard tool used to assess endothelial function [31]. In addition, various reactivity tests, coupled with techniques measuring skin blood flux, are used to noninvasively explore both endothelial and neurovascular microvascular functioning in humans [32].

First described by Mulvany and Halpern, vascular tone is measured by using myography in mouse models [33]. This instrument is used for the examination of isolated arteries, with internal diameters between 100-400 $\mu \mathrm{m}$ that are independent of homeostatic mechanisms such as blood flow or autonomic nervous control [34]. The conditions near the physiological setting obtained in myograph allows in-depth characterization of intrinsic vascular tone reactions to physiological and pharmacological stimuli [35]. According to active tension-length relation, force production and the sensitivity of arteries to different agonists are dependent on the extent of stretch [36]. There are two types of myographs for measuring vascular function and studying vascular tones known as the pressure myograph and wire myograph (also see DMT website for an introduction http://www.dmt.dk/default.asp?Action=Details\&Item=543). Pressure myograph may have some advantages over wire myograph such like: 1) micro resistance arteries with internal diameters of less than $500 \mu \mathrm{m}$ [37] can be studied whereas wire myograph is limited to large conduit arteries; 2) the risk to damage endothelium by wire is reduced; 3 ) the nature morphology of the arteries is maintained; and 4) the potential effects of a wide range of pressures and shear stress on artery dimension can be studied [35]. In addition, studying microarteries can be more informative than examining larger conduit arteries to understand the pathophysiological and molecular mechanisms underlying altered vascular tone in certain mouse models of cardiovascular diseases such as hypertension [35]. For example, endothelial dysfunction can be found in $2^{\text {nd }}$ order mesenteric arteries but not in the aortic rings of mice fed with a high fat diet for 8 weeks [38]. In vessel rings pre-contracted with phenylephrine (PE; $1 \mu \mathrm{M}$ ) [39], vascular tone reactivity can be grouped into endothelium-dependent reactivity (to acetylcholine, ACh; $10 \mathrm{nM}$ to $33 \mu \mathrm{M}$ ) and endothelium-independent reactivity (to sodium nitroprusside, SNP; $1 \mathrm{nM}$ to $10 \mu \mathrm{M}$ ), therefore we focus our discussion mainly on endotheliumdependent pathways.

Since high myocardial oxygen extraction occurs at basal conditions, additional metabolic demands may be met by increasing the myocardial blood supply. The coronary artery is capable of increasing the basal flow by at least three 


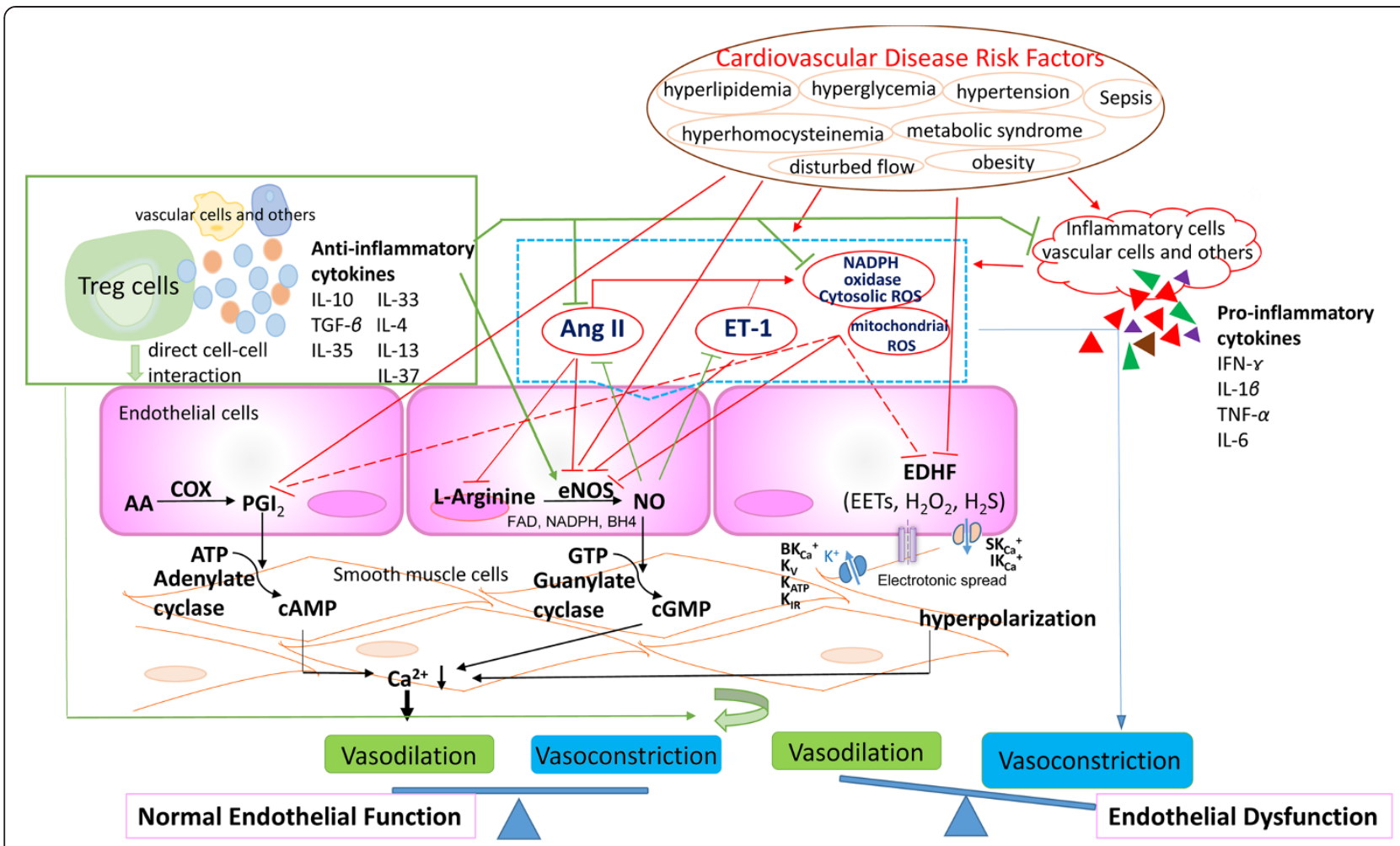

Figure 1 A new working model: Regulatory T cells and immunosuppressive/anti-inflammatory cytokines inhibit endothelial dysfunction. In physiological status, the interaction between endothelium-dependent vasoconstrictors (including Ang II, ET-1, ROS) and vasodilators (NO, EDHF and PGI2) maintain the endothelial function and equilibrium of vascular tone. The impairment of the balance between the vasoconstrictors and vasodilators is generally defined as the endothelial dysfunction. Under cardiovascular diseases risk factors stimuli, when vasodilation pathways being impaired or vasoconstriction being activated, endothelial dysfunction occurs. Regulatory T cells (Tregs) act on endothelial cells via cell-cell-interaction and/or immunosuppressive/antiinflammatory cytokines to inhibit endothelial dysfunction and restore normal vascular tone.

folds. This maximum increase in coronary blood flow is defined as "coronary artery reserve". This remarkable feature is regulated by various vasodilators and vasoconstrictors produced by coronary artery endothelial cells [40]. Not limited to coronary artery endothelium, endothelium generally are capable of producing vasodilators such as $\mathrm{NO}$, prostacyclin $\left(\mathrm{PGI}_{2}\right)$, and endothelium-derived hyperpolarizing factor (EDHF) as well as vasoconstrictors such as endothelin-1 (ET-1), angiotensin II (Ang II), and free radicals $[2,41]$ that maintain the physiologically balanced vascular tone.

\section{Endothelium-derived vasodilators \\ Nitric oxide}

Among several endothelium-dependent pathways that control vascular tone, the NO pathway is the most prominent in macrovasculature. $\mathrm{NO}$ is a key endotheliumderived relaxing factor, produced through the conversion of L-arginine to L-citrulline by the endothelial nitric oxide synthase (eNOS). Once produced in EC, NO diffuses freely into the vascular smooth muscle cells $(\mathrm{SMC})$ where it activates soluble guanylyl cyclase (sGC), which in turn catalyzes the formation of cyclic guanosine monophosphate (cGMP) and finally leads to the relaxation of the vascular smooth muscle [42]. NO is synthesized by a family of NO synthases (NOS) that include neuronal NOS (nNOS), eNOS and inducible NOS (iNOS). These three NOS share $50-60 \%$ homology at the amino acid sequence and all have an $\mathrm{N}$-terminal oxygenase domain with heme-, L-arginine- and tetrahydrobiopterin (BH4) binding domains, a central calmodulin ( $\mathrm{CaM}$ )-binding domain, a C-terminal reductase domain with nicotinamide adenine dinucleotide phosphate (NADPH), flavin adenine dinucleotide (FAD), and a flavin mononucleotide (FMN) binding site [43]. Biochemical and mechanical regulations of eNOS activity play an important role in physiological and pathophysiological responses. eNOS enzymatic activity can be regulated at multiple levels including gene transcription, mRNA stability, substrate, co-factor availability, post-translational modifications, and protein-protein interaction with heat shock protein 90(hsp90) and caveolins [44]. Phosphorylation of eNOS can take place at seven different phosphorylation sites at specific tyrosine $(\mathrm{Y})$, serine (S) and threonine (T). The identified Y sites localize to Y81 
and Y567, the S sites localize to S114, S615, S633, and S1177, and the T site localizes to T495 (based on the human eNOS sequence nomenclature) [43]. AKT-1-mediated phosphorylation of S615 and S1177 cooperate to enhance NO generation from eNOS at resting calcium levels, although there is a yin-yang relationship between T495 and S1177 with phosphorylation of one being correlated with dephosphorylation of the other. In addition, phosphorylation of eNOS at S114 decreases eNOS activity [43]. Mechanical shear stress activates eNOS by the phosphorylation of the serine residue 1177 and activation of protein kinase $\mathrm{B}$ (PKB, AKT), which itself is phosphorylated by phosphatidylinositol-3-kinase $\left(\mathrm{PI}_{3} \mathrm{~K}\right)$ [45]. Different from the maintained phosphorylation of serine residue of eNOS in shear stress-stimulated cells, serine 1177 phosphorylation of eNOS in bradykinin-stimulated cells is transient. This eNOS activation requires an elevation in intracellular free calcium concentration, formation of a complex with calmodulin and the removal of the inhibitory caveolin from the activated eNOS complex, although NO production is not affected by the components of $\mathrm{PI}_{3} \mathrm{~K}$-AKT pathway [46].

Besides being the main determinant of the basal vascular tone, NO serves as a natural counterpart to the actions of potent endothelium-derived contracting factors such as Ang II and ET-1. In turn, these factors can also regulate the expression of NOS and NO production [47-49]. Reduced NO bioavailability, resulting from either insufficient production or increased degradation of $\mathrm{NO}$, is one of the dominant features of endothelial dysfunction. eNOS requires critical cofactors, such as FAD, NADPH and BH4, to facilitate NO production [50]. In the absence of adequate levels of L-arginine or an essential amount of the cofactors, eNOS may become uncoupled and generate ROS including superoxide anions $\left(\mathrm{O}_{2}^{-}\right)$, and hydrogen peroxide $\left(\mathrm{H}_{2} \mathrm{O}_{2}\right)$ instead of nitrogen species [51]. Therefore, the availabilities of L-arginine and eNOS cofactors FAD, $\mathrm{NADPH}$, and $\mathrm{BH} 4$ are very important for $\mathrm{NO}$ availability and endothelial function.

\section{Endothelium-derived hyperpolarizing factor}

EDHF pathway also plays a significant role in vascular tone regulation, especially in small resistant vessels. It triggers potassium ions $\left(\mathrm{K}^{+}\right)$efflux, which prevents voltage-dependent calcium channel activation, leading to a decrease of the intracellular calcium concentration and relaxation of vascular SMC [52]. The chemical identity of EDHF has not yet been identified. In some cases, it has been found that members of the arachidonic acid (AA) derivatives known as eicosatrienoic acids (EETs) can mediate vasodilation. Agonists such as bradykinin stimulate endothelial G protein-coupled receptors (GPCR) provoking an increase in intracellular calcium in the EC, which activates phospholipase $A_{2}$
(PLA2) mediated AA production. AA metabolism by cytochrome P450 2C (CYP4502C) generates EET, which can stimulate calcium dependent potassium $\left(\mathrm{K}_{\mathrm{Ca}}^{+}\right)$channels. Open $\mathrm{K}_{\mathrm{Ca}}^{+}$channels allows for an efflux and accumulation of $\mathrm{K}^{+}$into the myoendothelial space that triggers the transmission of endothelial cell hyperpolarization to the vascular smooth muscle via gap junctions. In turn, smooth muscle cell hyperpolarization results in relaxation by the closing of voltage-gated channels leading to a fall in $\mathrm{Ca}^{2+}$ concentration and subsequent vasodilation [53]. Myoendothelial gap junctions play an important role in electrotonic spread hyperpolarization between EC and SMC. In a number of blood vessels in which myoendothelial coupling is strong, such as in the rat mesenteric artery, the EDHF pathway occurs. While in adult rat femoral artery, in which the smooth muscle and endothelial layers are not coupled electrically, EDHF pathway does not occur even though acetylcholine evokes hyperpolarization in the EC [54]. $\mathrm{K}_{\mathrm{Ca}}^{+}$channels have been divided into three types, small-conductance $\left(\mathrm{SK}_{-\mathrm{Ca}}^{+}\right)$, intermediateconductance $\left(\mathrm{IK}_{\mathrm{Ca}}^{+}\right)$and large-conductance $\left(\mathrm{BK}_{\mathrm{Ca}}^{+}\right)$channels. A combination of apamin (a specific inhibitor of $\mathrm{SK}_{\mathrm{Ca}}^{+}$) and charybdotoxin (a non-selective inhibitor of $\mathrm{BK}_{\mathrm{Ca}}^{+}, \mathrm{IK}_{\mathrm{Ca}}^{+}$and voltage-dependent $\mathrm{K}^{+}$-channels), which has been demonstrated to act selectively on endothelium [55], can completely block EHDF-mediated relaxation $[56,57] . \mathrm{SK}_{\mathrm{Ca}}^{+}$and $\mathrm{IK}_{\mathrm{Ca}}^{+}$channels are abundant in $\mathrm{EC}$ and their activation clearly engages in EDHF-induced vasodilation [58]. Meanwhile, as a specific inhibitor of $\mathrm{BK}_{\mathrm{Ca}}^{+}$, iberiotoxin cannot substitute for charybdotoxin or exclude the role of $\mathrm{BK}_{\mathrm{Ca}}^{+}$in EDHF-mediated response [59]. $\mathrm{BK}_{\mathrm{Ca}}^{+}$has been identified in SMC along with three other types of $\mathrm{K}^{+}$channels, voltage-dependent $\mathrm{K}^{+}(\mathrm{Kv})$ channels, ATPsensitive $\mathrm{K}^{+}(\mathrm{KATP})$ channels, and inward rectifier $\mathrm{K}^{+}(\mathrm{Kir})$ channels [60]. In addition, a study found that $\mathrm{IK}_{\mathrm{Ca}}^{+}$channels are expressed in proliferative SMC rather than normal SMC, which in turn can define the physiological properties of vascular smooth muscle [61].

Besides $\mathrm{K}^{+}$and EETs, $\mathrm{H}_{2} \mathrm{O}_{2}$ also activates calciumdependent potassium channels and has been demonstrated to function as a pivotal EDHF [62]. $\mathrm{H}_{2} \mathrm{O}_{2}$ plays an important role in coronary auto-regulation in cooperation with $\mathrm{NO}$ and adenosine [63]. In mouse mesenteric arteries, catalase can inhibit ACh-induced endotheliumdependent relaxation and cause hyperpolarization by catalyzing the decomposition of $\mathrm{H}_{2} \mathrm{O}_{2}$ to water and oxygen. This suggests $\mathrm{H}_{2} \mathrm{O}_{2}$ may also perform the role of EDHF in mouse mesenteric arteries [64]. However, catalase does not inhibit non-NO-, non- $\mathrm{PGI}_{2}$-mediated vasodilation in all arteries [63-65]. Upon ACh stimulation in eNOS knockout mice, the endothelium-produced $\mathrm{H}_{2} \mathrm{O}_{2}$ reduces dramatically, which indicates that eNOS is a major source of $\mathrm{H}_{2} \mathrm{O}_{2}$. In addition, a redox variant of $\mathrm{NO}$, nitroxyl anion $\left(\mathrm{NO}^{-}\right)$, has been proved to be an endogenously derived 
EDHF that can induce preserved vascular relaxation in the aorta from Ang II-treated hypertensive mice [66,67]. Recently, $\mathrm{H}_{2} \mathrm{~S}$ has also been suggested to be an EDHF. $\mathrm{H}_{2} \mathrm{~S}$ causes vascular EC and SMC hyperpolarization and vasodilation by activating the KATP, $\mathrm{SK}_{\mathrm{Ca}}^{+}$and $\mathrm{IK}_{\mathrm{Ca}}^{+}$channels through cysteine S-sulfhydration [68].

It has long been accepted that, unlike NO, which induces vasodilation in large conductance arteries, EDHF regulates vascular tone and reactivity in small resistance vessels [69]. However, recent in vivo studies found that cytochrome P-450-related EDHF is involved in the regulation of the peripheral conduit artery diameter at rest but not in the control of the basal vascular resistance in the healthy human forearm [70]. After inhibition of NO and prostacyclin, the inhibition of EET synthesis further decreases radial arterial blood flow and diameter. This indicates that EETs plays a potential compensatory role in maintaining basal tone when $\mathrm{NO}$ availability is diminished. In addition, it has been demonstrated that in hypercholesterolemia $\mathrm{K}_{\mathrm{Ca}}^{+}$channel-mediated vasodilation compensates for the reduced NO bioavailability [71]. Furthermore, the activity of EDHF is much higher in individuals with multiple risk factors than that in healthy subjects when compared to NO.

\section{Prostacyclin}

Prostacyclin, also termed as $\mathrm{PGI}_{2}$ is also an endotheliumreleased effective vasodilator, which functions by binding to GPCRs(G-protein-coupled receptors) to stimulate the production of cyclic adenosine monophosphate (cAMP) that subsequently activates protein kinase A (PKA) and leads to smooth muscle relaxation and vasodilation. $\mathrm{PGI}_{2}$ also inhibits vasoconstriction, platelet activation and further coagulation by counteracting the effects of the vasoconstrictor thromboxane $\mathrm{A} 2\left(\mathrm{TXA}_{2}\right) . \mathrm{PGI}_{2}$ and $\mathrm{TXA}_{2}$ are produced from AA metabolism mediated by cyclooxygenase (COX). There are two isoforms of COX, which mainly differ in their pattern of expression. COX-1 is expressed in most tissues, whereas COX-2 is usually absent but induced by various physiologic stimuli. COX-1 mostly produces TXA2 while the induction of COX-2 is associated with an increase in $\mathrm{PGI}_{2}$ production [72]. P38 and P44/42 mitogen-activated protein kinase (MAPK) pathways mediate the induction of COX-2. In recent years, the wildly accepted COX-2-dependent $\mathrm{PGI}_{2}$ production pathway has been challenged by the direct measurement of circulating $\mathrm{PGI}_{2}$ levels rather than by the use of urinary markers, which unveiled that it is COX-1, not COX-2, that is responsible for $\mathrm{PGI}_{2}$ production in healthy individuals [73]. The opposite conclusions engender controversy of $\mathrm{PGI}_{2}$ testing [74], although specific COX-2 inhibitors increase the risk of cardiovascular events, which supports that vascular COX-2 is an important protein for maintaining vascular hemostasis [72-74].
The three endothelium-dependent vasodilation pathways, $\mathrm{NO}, \mathrm{EDHF}$, and $\mathrm{PGI}_{2}$ do not appear to be mutually exclusive but act synergistically in a complex manner to maintain the vasculature health. In addition, the roles of these three components may vary among the vascular beds in different sizes and tissue locations [69]. Moreover, different pathways vary in time course. Many studies have shown that EDHF is more important during the earlier phase of endothelial dysfunction while $\mathrm{NO}$ and $\mathrm{PGI}_{2}$ are primarily responsible for later and more sustained parts of the vasodilator in response to acetylcholine or bradykinin in various arteries $[75,76]$.

\section{Endothelium-derived vasoconstrictors Reactive oxygen species}

As analyzed in our recent review [77], ROS can be derived from the transfer of electrons to molecular oxygen in the mitochondrial respiratory systems $[78,79]$ or produced by the activity of NADPH oxidases, which is co-localized with eNOS in subcellular compartments within EC [80]. This observation provides a direct link between NADPH oxidase and the endothelial function in humans. Small and transient amounts of $\mathrm{O}_{2}^{-}$can be beneficial for the endothelial function, through activation of eNOS via Src (a homolog gene highly similar to the v-src gene of Rous sarcoma virus)/PI3-kinase/Akt pathway [51]. High levels of ROS generated in pathological situations will reduce $\mathrm{NO}$ bioavailability by the binding of $\mathrm{O}_{2}^{-}$to form peroxynitrite $\left(\mathrm{ONOO}^{-}\right)$. This $\mathrm{ONOO}^{-}$coupling with $\mathrm{NO}$ results in an imbalance of vascular tension. In addition, NADPH-derived $\mathrm{H}_{2} \mathrm{O}_{2}$ impairs endothelial function by amplifying itself in vascular disease [81]. Elevated levels of ROS have been associated with endothelial dysfunction developed in diabetes mellitus, hypertension, hypercholesterolemia, obesity, atherosclerosis [82-86] and sepsis [87]. In addition, several inflammatory cytokines are induced by oxidant stress $[88,89]$ while cytokines themselves in turn lead to increased levels of ROS and reactive nitrogen species (RNS) in acute or chronic inflammation [90].

\section{Angiotensin II}

Ang II is part of the renin-angiotensin system that causes vasoconstriction, which increases blood pressure. Ang II stimulates $\mathrm{Gq}$ protein in vascular SMC, which increases intracellular calcium levels by an $\mathrm{IP}_{3}$-dependent mechanism that consequently leads to contraction. In addition, Ang II enhances vascular arginase activity that impairs NO production by decreasing L- arginine availability $[91,92]$. It has been demonstrated that the p38 MAPK pathway participates in this arginase upregulation [93]. Moreover, Ang II also increases superoxide production, which leads to eNOS uncoupling $[48,94]$ in EC. Meanwhile, other studies demonstrated that the activation of the COX-1 pathway is involved in Ang II- 
induced development of endothelial dysfunction in small resistance arteries $[95,96]$.

\section{Endothelin-1}

ET-1, a 21-aa peptide released by EC, is a natural counterpart of $\mathrm{NO}$, which is normally kept in balance by many mechanisms. ET-1 and NO take part in a paracrine regulation of each other, and the release of ET-1 is blocked by endothelium-derived NO $[97,98]$. In pathological situations, ET-1 upregulates the expression of caveolae-1, which appears to be a key negative regulator protein for eNOS activity which leads to eNOS inhibition [99]. In addition, ET-1 can also increase ROS production attributing to NO degradation [100]. Selective endothelin receptor type $\mathrm{A}\left(\mathrm{ET}_{\mathrm{A}}\right)$ and dual $\left(\mathrm{ET}_{\mathrm{A}}+\mathrm{ET}_{\mathrm{B}}\right)$ antagonists improve NO bioavailability and endothelial function in pathological situations. Transgenic mice that overexpress ET-1 specifically in EC (eET-1) have an increase of endothelial dysfunction, vascular remodeling, oxidative stress, and inflammation [100,101]. Recently, a study demonstrated that ET-1-induced vascular hypertrophy and oxidative stress participate in innate immunity system activation $[102,103]$. Overexpression of ET-1 in EC causes an increase in monocytes/macrophage infiltration into adventitia, which is similar to the findings in mice infused with Ang II [104]. Colony stimulation factor-1 (CSF1) deficiency, a gene mutation impairing monocyte and macrophage production and maturation, can prevent this vascular damage. This finding provides evidence of the roles of monocyte/macrophage as well as innate immunity in ET-1-induced vascular injury.

\section{Role of anti-inflammatory cytokines in endothelial dysfunction}

The delicate balance between pro- and anti-inflammatory cytokines determines the net effect of an inflammatory response. Perturbations in this equilibrium can drive the host defense immune response either towards chronic inflammation (pro-inflammatory) or towards healing (anti-inflammatory). Exposure of endothelial cells to pro-inflammatory cytokines leads to transient and reversible endothelial dysfunction $[105,106]$. A number of anti-inflammatory treatment strategies improve endothelial function by preventing pro-inflammatory cytokine synthesis. Anti-inflammatory cytokines are a series of immune-regulatory molecules that control the proinflammatory cytokines response, which consequently reduces inflammation and promotes healing. In addition, an elevation in the level of anti-inflammatory cytokines can also be found in the development of vascular disease [107], which reflects an early compensatory mechanism and serves as an indicator of pro-inflammatory reactions. Major anti-inflammatory cytokines include IL-1Ra, IL-4, IL-10, IL-11, IL-13 and TGF- $\beta$. Several newly found cytokines, such as IL-33, IL-35, and IL-37 also participate in regulating the function of EC. The following will discuss two of these anti-inflammatory cytokines including IL-10 and TGF- $\beta$ in detail.

\section{Interleukin-10}

IL-10 is an anti-inflammatory cytokine produced by many types of immune cells, such as monocytes, macrophages, type $2 \mathrm{~T}$ helper cells (Th2), mast cells, natural killer (NK) cells, and CD4 + CD25 + Foxp3+ regulatory T cells (Tregs). Its primary biological function is to limit and terminate inflammatory responses and regulate the differentiation and proliferation of several immune cells. IL-10 receptor 1 (IL-10R1) and IL-10R2 are two subunits of the IL-10 receptor that are expressed by hematopoietic and nonhematopoietic cells. The receptor expression has also been observed in endothelial cells $[108,109]$, which provides the structural evidence for IL-10 to not only counteract pro-inflammatory cytokines but also potentially inhibit endothelial dysfunction directly. Many studies have found that IL-10 is a key mediator of vascular protection in atherosclerosis, type II diabetes and hypertension [110-112]. IL-10 is shown to protect endothelial function by initiating the degradation of several cytokine mRNAs, inhibiting the production of monocyte/macrophage- and neutrophil-derived cytokines [113] and attenuating induction of superoxide generation within the vascular wall $[114,115]$. Clinically, in patients with coronary artery disease, IL-10 serum level acts as an independent predictor of the endothelium-mediated vasodilator response of the forearm circulation [116]. Furthermore, IL-10 prevents the impairment of endothelial dysfunction induced by elevated levels of C-reactive proteins [116].

IL-10 also attenuates inflammatory responses by its antioxidant properties. It plays a protective role in blood vessels by inhibiting NADPH oxidase activity and ROS production [111,117]. In addition, IL-10 can restore Ang II-induced endothelium-dependent relaxation impairment measured by wire myographs in healthy murine aorta rings [118]. Mechanistically, Ang II leads to endothelial dysfunction by increasing gp91phox (NOX2) expression, which is a subunit of NADPH oxidase, while IL-10 inhibits this response by normalizing NADPH oxidase protein expression. In IL-10 knockout (IL-10 ${ }^{-/-}$) mice, carotid arteries and thoracic aortas show a marked augmentation of vascular dysfunction after systemic treatment with Ang II that can be prevented by the treatment with superoxide dismutase-mimetic compound TEMPOL [112]. In Ang II-infused hypertensive mice, IL-10 that is released by transferred $\mathrm{CD} 4{ }^{+} \mathrm{CD} 25^{+}$natural Treg cells from wild type mice significantly reduces NAPDH oxidase activity and systolic blood pressure; while the transfer of Tregs isolated from IL-10 $10^{-/-}$mice has no effect on the hypertension mice. Collectively, these results suggest that 
IL-10 generated by the immunosuppressive Treg cells protects against Ang II-induced vascular dysfunction and hypertension development by suppressing oxidative stress [119].

In recent studies on aging, old $\mathrm{IL}-10^{-/-}$mice are shown to have stiffer vessels and more severe endotheliumdependent relaxation impairment than wild type mice, which can be reversed by a scavenger of superoxide [120]. In addition, gp91phox is significantly induced in IL-10 ${ }^{-/}$ than that of wild type mice in aging vessels. Furthermore, it is demonstrated that IL-10 protects against age-related endothelial dysfunction by the inhibition of oxidative stress. Aside from oxidative stress, it was also found that there is an increase of COX-2 activity and consequently activation in thromboxane $\mathrm{A}_{2}$ receptor instead of $\mathrm{PGI}_{2}$ in older IL-10 ${ }^{-/-}$mice [121].

In vitro, IL-10 suppresses the production of proinflammatory cytokines such as interferon- $\gamma$ (IFN- $\gamma)$, IL$1 \beta$, TNF- $\alpha$, and IL- 6 by immune cells including $\mathrm{T}$ cells, monocytes, macrophages and dendritic cells to produce [113,122-124]. Meanwhile, IL-10 blocks the activity of NF- $\mathrm{kB}$ [125], which is a key pro-inflammatory transcription factor [126-128]. In vivo, IL-10 dampens the pro-inflammatory effects of IL-1 and TNF by stimulating IL-1Ra and soluble TNF receptors (sTNFR) production [129]. In TNF- $\alpha$-treated mouse models, impairment of vascular relaxation is accompanied with a reduction of eNOS, which can be counteracted by IL-10 which induces eNOS expression and attenuates superoxide production [130]. In addition, by using mouse aortic rings in a myograph, TNF- $\alpha$ triggers a significant decrease in AChinduced relaxation, which can be restored by IL-10.

The Janus kinase/signal transducers and activators of transcription (JAK/STAT) signaling pathway plays an essential role in mediating the anti-inflammatory actions of IL-10 [131]. In human EC, IL-10 up-regulates eNOS expression and activity mediated by the activation of STAT3 [132]. IL-10 and IL-10 receptor interaction involves the JAK family tyrosine kinases Jak1 and Tyk3 that induce tyrosine phosphorylation and the activation of latent transcription factors STAT3, STAT1, and STAT5 [133,134]. IL-10 inhibits pro-inflammatory cytokine production in the macrophages via a JAK/STAT3dependent pathway [135]. In IL-10 ${ }^{-/-}$mice, STAT3 phosphorylation induction does not occur.

Aside from the JAK/STAT pathway, recent studies suggest that IL-10 also confers endothelial protection through several other signaling pathways. IL-10 inhibits the IL-1induced inhibitor of kappa B (IкB) expression, decreases $\mathrm{I} \kappa \mathrm{B}$ phosphorylation and causes an increase in the eNOS activity [136]. In addition, IL-10 is associated with the inhibition of extracellular signal-regulated protein kinases 1 and $2($ ERK1/2) activity and the MAPK kinase (MEK)/ ERK pathway [137-139]. In TNF- $\alpha$-infused IL-10 ${ }^{-/-}$mice there is an increase of total and phosphorylated ERK1/2 [140], and the aorta and mesenteric arteries isolated from those mice display increased contractile responses to ET-1 through the $\mathrm{ET}_{\mathrm{A}}$ receptor, which can be abrogated by the ERK1/2 inhibitor PD-98059. This result demonstrates that IL-10 attenuates ET-1 induced vascular injury through the inhibition of the ERK1/2 pathway.

Emerging evidence also suggests that IL-10 plays a major role in suppressing endothelial dysfunction in lipopolysaccharide (LPS)-induced endotoxemia. In LPSinduced endotoxemia, activated ERK1/2 can induce higher expression of IL-10. IL-10 in turn restores eNOS-mediated relaxation by inhibiting production of ROS in monocytes and neutrophils. Meanwhile, it also decreases the production of pro-inflammatory cytokines such as TNF- $\alpha$ and IL-6, leading to an attenuation of septic shock [141]. Mechanistically, IL-10 inhibits the transcription of several inflammatory genes that are induced by the Toll-like receptor (TLR) signaling, such as COX-2, IL-8, and IL-1 [142,143]. This response can be completely or partially abrogated by the PI3K or Akt1/2 inhibitor. The PI3KAkt-glycogen synthase kinase 3 (GSK3) pathway regulates IL-10-induced gene expression and controls the ability of IL-10 to suppress a set of inflammatory genes [144].

In summary, as a cytokine synthesis inhibitor factor (CSIF), IL-10 inhibits a broad spectrum of the functions of activated monocytes/macrophages and T cells, including pro-inflammatory cytokine synthesis, and NO production. It also contributes to an essential part in the balance between pro- and anti-inflammatory cytokines.

\section{Transforming growth factor- $\beta$}

TGF- $\beta$ is a multifunctional growth factor capable of inducing cell proliferation, differentiation, programmed cell death, and stimulating matrix deposition. TGF- $\beta$ family members are also a set of pleiotropic secreted signaling molecules with unique and potent immunoregulatory properties that not only significantly contribute to establishing and maintaining the vascular wall integrity [145], but also participate in the process of wound healing and tissue fibrosis [146,147]. Various types of cells, such as all the immune cell lines, secrete TGF- $\beta$. There are at least three isoforms including TGF- $\beta 1$, TGF$\beta 2$ and TGF- $\beta 3$, in which TGF- $\beta 1$ is predominantly expressed in the immune system and has long been known to mediate remarkable actions in the pathogenesis of many vascular diseases. TGF- $\beta$ performs anti-inflammatory effects and plays an important role in inhibiting vascular disease. Three types of TGF- $\beta$ receptors are highly expressed in endothelial cells, in which Type I and II receptors are expressed by all the endothelial cells while Type III receptors are mainly located in microvascular endothelial cells [148]. The expressions of TGF- $\beta$ receptors in endothelial cells provide the structural evidence for TGF- $\beta$ to not only 
counteract pro-inflammatory cytokines but also potentially inhibit endothelial dysfunction directly. Moreover, a significant increase in eNOS mRNA levels can be found in TGF$\beta$ treated EC [149]. In D-glucose stimulated human umbilical vein endothelium cells (HUVEC), TGF- $\beta$ binds to type II TGF- $\beta$ receptors and increases $\mathrm{L}$-arginine transport and $\mathrm{NO}$ synthesis, which protects against hyperglycemia-induced endothelial dysfunction [150]. In addition, TGF- $\beta 1$ knockout mice develop multifocal inflammatory disease associated with increased inflammatory cytokine production, which demonstrates that TGF- $\beta$ is essential in immune suppression under physiological conditions [151].

In EC, TGF- $\beta$ increases eNOS expression by activating Smad2, a transcription factor, which interacts with the eNOS promoter [149]. Meanwhile, NO inversely controls the transcription of TGF- $\beta$ via the endothelial NO/ cGMP/PKG pathway and interferes with TGF- $\beta /$ Smad2 signaling in vitro and in vivo $[149,152]$. With NO donor treatment, EC show a decreased response to TGF- $\beta$ and suppressed TGF- $\beta$ target gene expression. Reversely, in eNOS deficient mice, the impairment of NO signaling leads to the upregulation and activation of TGF- $\beta$, which accelerates vascular injuries. These results show that the TGF- $\beta$ dependent effects are complex and can be modulated by NO bioavailability. In response to shear stress, TGF- $\beta 3$ plays a protective role in maintaining EC homeostasis accompanied by eNOS phosphorylation that leads to the release of NO [153]. In a high salt intake mouse model, TGF- $\beta$ induced by an excess salt diet restores endothelial $\mathrm{NO}$ production via AKT activation and NOS3 phosphorylation as well as alleviates arterial compliance impairment, which forms an inhibitory feedback loop during the vascular function alteration [154].

The inhibitory effects of TGF- $\beta$ are also in association with Tregs, which perform important immunosuppressive effects [155]. TGF- $\beta$ converts CD $4^{+} \mathrm{CD} 25^{-}$effector $\mathrm{T}$ cells into $\mathrm{CD} 4^{+} \mathrm{CD} 25^{+}$Treg cells by inducing Foxp3 expression. TGF- $\beta$ signaling is not only required for the survival of peripheral Tregs, but also for the maintenance of Treg suppressive function. Further studies found that TGF- $\beta 1$ secreted by effector $\mathrm{T}$ cells is dispensable for the development and maintenance of Treg cells, while local TGF- $\beta 1$ production from infiltrating Treg cells appears to be required for Treg immunosuppressive functions [156]. It is well known that Treg cells play an active role in the prevention of cardiovascular diseases [157]. Treg adoptive transfer prevents Ang II-induced hypertension and alleviates aldosterone-induced impairment of the vasodilatory response of resistance mesenteric arteries to Ach [104]. The NOS inhibitor significantly decreases the protective effects of Treg cells, indicating that Treg cells confer protection against the Ang II induced vasodilatory responses through a NO-dependent pathway. In addition, Ang II-induced NADPH oxidase activity can be prevented by Treg adoptive transfer. Thus, the suppressive function in inhibiting both macrophages and $\mathrm{T}$ lymphocytes from Tregs is associated with Tregs' contribution to the inhibition of Ang II-induced oxidative stress.

All together, there is a considerable interest in TGF- $\beta$ for its potential role to be used as a therapeutic target, which prevents endothelial dysfunction through either inducing NO production or counteracting oxidative stress.

\section{Other anti-inflammatory cytokines}

IL-37, previously known as IL-1 family member 7, has been identified as a new anti-inflammatory cytokine. It is expressed in several tissues and inflammatory cells. Mice with transgenic expressions of IL-37 are protected from LPS-induced endotoxemia and show markedly reduction of liver damage and improved lung and kidney function [158]. Meanwhile, through the interaction with intracellular smad3, IL-37 significantly decreases the expression of various pro-inflammatory cytokines, such as IL-6, IL-1 $\beta$, IL-17 and IFN- $\gamma$ both in plasma and organs when compared with vehicle-treat control mice. It has also been observed that IL-37 suppresses the production of pro-inflammatory cytokines in macrophages and epithelial cells, but its role in regards to EC is yet to be explored.

IL-33, also a member of the IL-1 cytokine family, is another newly identified anti-inflammatory cytokine [159]. IL-33 shows various protective effects in the cardiovascular system when ligated with ST2 (IL-33 receptor), a member of the Toll-interleukin 1 receptor (TIR) superfamily. IL-33 markedly decreases the aortic sinus atherosclerotic lesion size in apolipoprotein $\mathrm{E}(\mathrm{ApoE})^{-/-}$mice fed on a high fat diet, which is accompanied by the induction of IL-4, IL-5, and IL-13 and reduction of IFN- $\gamma$ in the serum [160]. In type II diabetes, IL-33 shows protective metabolic effects by improving insulin tolerance, as well as reducing fasting glucose and adiposity [161]. So far, the molecular mechanisms underlying IL-33's protective effects are not fully understood. Recently, it was found that IL-33 is widely expressed in normal human tissues such as branched blood vessels, lymphoid tissues, adipocytes, cardiac fibroblasts, and even in human tumors. As a novel nuclear marker, IL-33 has been identified as an endogenous alarm in the immune system when the endothelium gets injured during infection and stress [162].

IL-4 and IL-13 both decrease the sensitivity of vascular EC to complement-mediated killing and apoptosis through the activation of a $\mathrm{PI}_{3} \mathrm{~K} / \mathrm{Akt}$ Pathway [163]. In addition, IL-4 protects EC from complement injury by upregulating claudin-5 through JAK/STAT6 and FoxO1 activation [164]. 
As a member of the IL-12 family, IL-35 has been identified as a novel anti-inflammatory/immunosuppressive cytokine generated by Tregs [165] and B cells [166,167]. We found that unlike IL-10 and TGF- $\beta$, IL-35 is not constitutively expressed in tissues and is mainly produced by inflammatory stimuli in EC, SMC and monocytes [168]. IL-35 also triggers $\mathrm{CD} 4^{+} \mathrm{CD} 25^{-} \mathrm{T}$ effector cell transformation into $\mathrm{CD} 4{ }^{+} \mathrm{CD} 25^{+}$independent of Foxp3 expression. However, the potential effect of IL-35 on endothelial dysfunction remains unknown.

\section{MicroRNA and endothelial dysfunction}

MicroRNAs (miRNAs) are a recently discovered class of posttranscriptional modulators of gene expression that have an essential role in vascular diseases $[169,170]$. They are a group of highly conserved, small, non-coding RNAs that, after maturation and entry into the RNA interference pathway, inhibit specific gene expression. Specific microRNAs can be regulated by inflammatory stimuli and certain microRNAs can act as mediators of inflammatory stimuli. In a human acute monocytic leukemia cell line, LPS stimulates the expression of miR-146a, miR-132 and $m i R-155$. Overexpression of $m i R-146 a$ inhibits not only the expression of interleukin-1 receptor-associated kinase and TNF receptor-associated factor $6 \mathrm{~s}$ [171], but also the expression of IL- 6 and IL-8 [172,173]. In turn, the induction of $m i R-155$, which is mediated by NFkB and the activator protein-1 (Ap-1) pathway, inhibits the expression of IL-8 $[174,175]$, which ultimately demonstrates a negative feedback loop involving microRNAs in an inflammatory response. Some miRNAs were proven to be highly expressed in EC in vitro [176]. TNF induced miR-31, miR17-3p and miR-126 significantly increase the expression of E-selectin, ICAM-1 and VCAM-1 in EC $[177,178]$. Transfections with mimics of these miRNAs decrease neutrophil adhesion to EC [177]. miR-181b, which is decreased by TNF, can down-regulate the NF-kB-responsive genes such as VCAM-1 and E-selectin in EC in vitro and in vivo [179]. In miR-10a knockdown human aortic EC, MCP-1 (monocyte chemotactic protein 1), IL-6, IL-8, VCAM-1 and E-selectin are highly elevated, which contributes to athero-susceptible phenotypes in vivo [180], suggesting that miR-10a suppresses atherogenesis.

In the aspect of regulating vascular tone, a recent report found that miR-222/221 controls eNOS protein levels after a member of the RNase III family know as dicer is knockdown [181]. Induced by shear stress, miR-21 can stimulate the phosphorylation of NOS and thereby increase NO production [182]. In contrast, miR-155 causes a reduction of NO by decreasing NOS expression [183]. In addition to mediating $\mathrm{NO}$-derived vasodilation, microRNAs also play a role in regulating vasoconstriction. A recent report [184] found that miR-125a/b-5p can suppress oxidized low density lipoprotein (oxLDL) induced
ET-1 expression by directly repressing prepro-ET-1 mRNA expression.

In summary, working together with the classical antiinflammatory cytokines, anti-inflammatory/anti-atherogenic microRNAs $[169,170]$, as a new concept we discussed, could be an important therapeutic target for protecting against endothelial dysfunction and controlling cardiovascular diseases.

\section{Conclusions}

Endothelial dysfunction has been known as a wellestablished response to cardiovascular risk factors and precedes the development of cardiovascular diseases. Anti-inflammatory cytokines protect against the impairment of endothelial function by counteracting the effects of pro-inflammatory cytokines and suppressing oxidative stress. Further studies performed on the inhibitory properties of anti-inflammatory cytokines on endothelial dysfunction may provide novel promising therapeutic strategies for the treatment of cardiovascular diseases.

\section{Abbreviations}

AA: Arachidonic acid; Ach: Acetylcholine; Ang II: Angiotensin II: ATP: Adenosine triphosphate; $\mathrm{BH} 4$ : Tetrahydrobiopterin; $\mathrm{BK}_{\mathrm{Ca}}^{+}$: Large-conductance channels; cAMP: Cyclic adenosine monophosphate; CGMP: Cyclic guanosine monophosphate; COX: Cyclooxygenase; EC: Endothelial cells; EDHF: Endothelium-derived hyperpolarizing factor; EETs: Eicosatrienoic acids; eNOS: Endothelial nitric oxide synthase; ERK1/ 2: Extracellular signal-regulated protein kinases 1 and 2; ET-1: Endothelin-1; $\mathrm{ET}_{\mathrm{A}}$ : Endothelin receptor type A; FAD: Flavin adenine dinucleotide; GTP: Guanosine triphosphate; GPCRs: G-protein-coupled receptors $\mathrm{H}_{2} \mathrm{O}_{2}$ : Hydrogen peroxide; ICAM-1: Intercellular adhesion molecule-1;

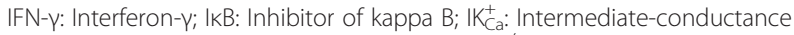
channels; IL-1Ra: IL-1 receptor antagonist; IL-10-/-: IL-10 knockout; JAK: JANUS kinase; $\mathrm{K}^{+}$: Potassium ions; $\mathrm{K}_{\text {ATP: }}$ ATP-sensitive $\mathrm{K}^{+}\left(\mathrm{K}_{\text {ATP }}\right)$ channels; $\mathrm{K}_{\mathrm{Ca}}^{+}$: Calcium dependent potassium channels Kir, inward rectifier $\mathrm{K}^{+}$channels; Kv: Voltage-dependent $\mathrm{K}^{+}$channels; LPS: Lipopolysaccharide; MAPK: Mitogen-activated protein kinase; MiRNAs: MicroRNAs; NADPH: Nicotinamide adenine dinucleotide phosphate; $\mathrm{NO}$ : Nitric oxide; $\mathrm{O}_{2}^{-}$: Superoxide anions; $\mathrm{ONOO}^{-}$: Peroxynitrite; $\mathrm{Pl}_{3} \mathrm{~K}$ : Phosphatidylinositol-3-kinase; $\mathrm{PGI}_{2}$ : Prostacyclin; ROS: Reactive oxygen species; STAT: Signal transducers and activators of transcription; SK Ca: Small-conductance channels; SMC: Smooth muscle cells; TGF- $\beta$ : Transforming growth factor- $\beta$; TNF-a: Tumor necrosis factor-a; Treg: Regulatory T cells; TXA 2 : Thromboxane A2; VCAM-1: Vascular cell adhesion molecule-1.

\section{Competing interests}

The authors declare that they have no competing interests.

\section{Authors' contribution}

YS carried out the primary literature search and drafted the manuscript. ZC, $\mathrm{X} \mathrm{L}$, and $\mathrm{VC}$ provided material input and helped revising the manuscript. HW and XFY supervised the manuscript writing and provided field expertise. All authors read and approved the final manuscript.

\section{Acknowledgements}

This work is partially supported by NIH grants to Drs. XF. Yang and H. Wang

Received: 30 July 2014 Accepted: 13 October 2014

Published online: 31 October 2014

\section{References}

1. Aird WC: Endothelial cell heterogeneity. Cold Spring Harb Perspect Med 2012, 2(1):a006429. 
2. Aird WC: Endothelium as an organ system. Crit Care Med 2004, 32(5 Suppl):S271-S279

3. Jaffe EA: Cell biology of endothelial cells. Hum Pathol 1987, 18(3):234-239.

4. Mai J, Virtue A, Shen J, Wang H, Yang XF: An evolving new paradigm: endothelial cells-conditional innate immune cells. J Hematol Oncol 2013, $6: 61$.

5. Deanfield J, Donald A, Ferri C, Giannattasio C, Halcox J, Halligan S, Lerman A, Mancia G, Oliver JJ, Pessina AC, Rizzoni D, Rossi GP, Salvetti A, Schiffrin EL, Taddei S, Webb DJ, Working Group on Endothelin and Endothelial Factors of the European Society of Hypertension: Endothelial function and dysfunction. Part I: methodological issues for assessment in the different vascular beds: a statement by the Working Group on Endothelin and Endothelial Factors of the European Society of Hypertension. $J$ Hypertens 2005, 23(1):7-17

6. Yang $X F$, Yin $Y$, Wang $H$ : Vascular inflammation and atherogenesis are activated via receptors for pamps and suppressed by regulatory t cells. Drug Discov Today Ther Strateg 2008, 5(2):125-142.

7. Boisrame-Helms J, Kremer H, Schini-Kerth V, Meziani F: Endothelia dysfunction in sepsis. Curr Vasc Pharmacol 2013, 11(2):150-160.

8. Hansell C, Nibbs R: Professional and part-time chemokine decoys in the resolution of inflammation. Sci STKE 2007, 2007(384):e18.

9. Trayhurn P, Wood IS: Signalling role of adipose tissue: adipokines and inflammation in obesity. Biochem Soc Trans 2005, 33(Pt 5):1078-1081.

10. Pedersen BK, Febbraio MA: Muscles, exercise and obesity: skeletal muscle as a secretory organ. Nat Rev Endocrinol 2012, 8(8):457-465.

11. Miller $\mathrm{Yl}$, Choi SH, Wiesner P, Fang L, Harkewicz R, Hartvigsen K, Boullier A, Gonen A, Diehl CJ, Que X, Montano E, Shaw PX, Tsimikas S, Binder CJ, Witztum JL: Oxidation-specific epitopes are danger-associated molecular patterns recognized by pattern recognition receptors of innate immunity. Circ Res 2011, 108(2):235-248.

12. Jialal I, Kaur H, Devaraj S: Toll-like receptor status in obesity and metabolic syndrome: a translational perspective. J Clin Endocrinol Metab 2014, 99(1):39-48

13. Lackie JM: A Dictionary of Biomedicine. 1st edition. Oxford: Oxford University Press; 2010.

14. Munoz C, Carlet J, Fitting C, Misset B, Bleriot JP, Cavaillon JM: Dysregulation of in vitro cytokine production by monocytes during sepsis. J Clin Invest 1991, 88(5):1747-1754

15. Kasai T, Inada K, Takakuwa T, Yamada Y, Inoue Y, Shimamura T, Taniguchi S, Sato S, Wakabayashi G, Endo S: Anti-inflammatory cytokine levels in patients with septic shock. Res Commun Mol Pathol Pharmacol 1997, 98(1):34-42.

16. Murdaca G, Spano F, Cagnati P, Puppo F: Free radicals and endothelial dysfunction: potential positive effects of TNF-alpha inhibitors. Redox Rep 2013, 18(3):95-99.

17. Kusuhara M, Isoda K, Ohsuzu F: Interleukin-1 and occlusive arterial diseases. Cardiovasc Hematol Agents Med Chem 2006, 4(3):229-235.

18. Aroor AR, McKarns S, Demarco VG, Jia G, Sowers JR: Maladaptive immune and inflammatory pathways lead to cardiovascular insulin resistance. Metabolism 2013, 62(11):1543-1552.

19. Deanfield JE, Halcox JP, Rabelink TJ: Endothelial function and dysfunction: testing and clinical relevance. Circulation 2007, 115(10):1285-1295.

20. Pober JS, Sessa WC: Evolving functions of endothelial cells in inflammation. Nat Rev Immunol 2007, 7(10):803-815.

21. Bautista LE: Inflammation, endothelial dysfunction, and the risk of high blood pressure: epidemiologic and biological evidence. J Hum Hypertens 2003, 17(4):223-230

22. Hadi HA, Carr CS, Al Suwaidi J: Endothelial dysfunction: cardiovascular risk factors, therapy, and outcome. Vasc Health Risk Manag 2005 1(3):183-198.

23. van den Oever IA, Raterman HG, Nurmohamed MT, Simsek S: Endothelial dysfunction, inflammation, and apoptosis in diabetes mellitus. Mediators Inflamm 2010, 2010:792393.

24. Cai $H$, Harrison DG: Endothelial dysfunction in cardiovascular diseases: the role of oxidant stress. Circ Res 2000, 87(10):840-844.

25. Cai H: Hydrogen peroxide regulation of endothelial function: origins, mechanisms, and consequences. Cardiovasc Res 2005, 68(1):26-36.

26. $\mathrm{Xu} \mathrm{J,} \mathrm{Zou} \mathrm{MH:} \mathrm{Molecular} \mathrm{insights} \mathrm{and} \mathrm{therapeutic} \mathrm{targets} \mathrm{for} \mathrm{diabetic}$ endothelial dysfunction. Circulation 2009, 120(13):1266-1286.

27. Sprague $A H$, Khalil RA: Inflammatory cytokines in vascular dysfunction and vascular disease. Biochem Pharmacol 2009, 78(6):539-552.
28. Frangogiannis NG: Regulation of the inflammatory response in cardiac repair. Circ Res 2012, 110(1):159-173.

29. Banchereau J, Pascual V, O'Garra A: From IL-2 to IL-37: the expanding spectrum of anti-inflammatory cytokines. Nat Immunol 2012 , 13(10):925-931.

30. Sitia S, Tomasoni L, Atzeni F, Ambrosio G, Cordiano C, Catapano A Tramontana S, Perticone F, Naccarato P, Camici P, Picano E, Cortigiani L, Bevilacqua M, Milazzo L, Cusi D, Barlassina C, Sarzi-Puttini P, Turiel M: From endothelial dysfunction to atherosclerosis. Autoimmun Rev 2010 9(12):830-834.

31. Stoner $L$, Sabatier MJ: Use of ultrasound for non-invasive assessment of flow-mediated dilation. J Atheroscler Thromb 2012, 19(5):407-421.

32. Roustit $M$, Cracowski JL: Assessment of endothelial and neurovascular function in human skin microcirculation. Trends Pharmacol Sci 2013, 34(7):373-384.

33. Mulvany MJ, Halpern W: Mechanical properties of vascular smooth muscle cells in situ. Nature 1976, 260(5552):617-619.

34. Spiers A, Padmanabhan N: A guide to wire myography. Methods Mol Med 2005, 108:91-104.

35. Shahid M, Buys ES: Assessing murine resistance artery function using pressure myography. J Vis Exp 2013, (76):e50328.

36. Bridges LE, Williams CL, Pointer MA, Awumey EM: Mesenteric artery contraction and relaxation studies using automated wire myography. $J$ Vis Exp 2011, (55):e3119.

37. Mulvany MJ, Aalkjaer C: Structure and function of small arteries. Physiol Rev 1990, 70(4):921-961.

38. Lei C, Yu B, Shahid M, Beloiartsev A, Bloch KD, Zapol WM: Inhaled nitric oxide attenuates the adverse effects of transfusing stored syngeneic erythrocytes in mice with endothelial dysfunction after hemorrhagic shock. Anesthesiology 2012, 117(6):1190-1202.

39. Cheng Z, Jiang X, Kruger WD, Pratico D, Gupta S, Mallilankaraman K Madesh $M$, Schafer Al, Durante W, Yang X, Wang H: Hyperhomocysteinemia impairs endothelium-derived hyperpolarizing factor-mediated vasorelaxation in transgenic cystathionine beta synthase-deficient mice. Blood 2011, 118(7):1998-2006.

40. Gutierrez E, Flammer AJ, Lerman LO, Elizaga J, Lerman A, Fernandez-Aviles F: Endothelial dysfunction over the course of coronary artery disease. Eur Heart J 2013, 34(41):3175-3181.

41. Cheng Z, Yang $X$, Wang H: Hyperhomocysteinemia and endothelial dysfunction. Curr Hypertens Rev 2009, 5(2):158-165.

42. Pacher $P, B e c k m a n$ JS, Liaudet L: Nitric oxide and peroxynitrite in health and disease. Physio/ Rev 2007, 87(1):315-424.

43. Rafikov R, Fonseca FV, Kumar S, Pardo D, Darragh C, Elms S, Fulton D, Black SM: eNOS activation and NO function: structural motifs responsible for the posttranslational control of endothelial nitric oxide synthase activity. J Endocrinol 2011, 210(3):271-284

44. Kashiwagi S, Atochin DN, Li Q, Schleicher M, Pong T, Sessa WC, Huang PL: eNOS phosphorylation on serine 1176 affects insulin sensitivity and adiposity. Biochem Biophys Res Commun 2013, 431(2):284-290.

45. Dimmeler S, Fleming I, Fisslthaler B, Hermann C, Busse R, Zeiher AM: Activation of nitric oxide synthase in endothelial cells by Akt-dependent phosphorylation. Nature 1999, 399(6736):601-605.

46. Fleming I, Fisslthaler B, Dimmeler S, Kemp BE, Busse R: Phosphorylation of $\operatorname{Thr}(495)$ regulates $\mathrm{Ca}(2+) /$ calmodulin-dependent endothelial nitric oxide synthase activity. Circ Res 2001, 88(11):E68-E75.

47. Olson SC, Dowds TA, Pino PA, Barry MT, Burke-Wolin T: ANG II stimulates endothelial nitric oxide synthase expression in bovine pulmonary artery endothelium. Am J Physiol 1997, 273(2 Pt 1):L315-L321.

48. Marasciulo FL, Montagnani M, Potenza MA: Endothelin-1: the yin and yang on vascular function. Curr Med Chem 2006, 13(14):1655-1665.

49. Salvemini D, Misko TP, Masferrer JL, Seibert K, Currie MG, Needleman P: Nitric oxide activates cyclooxygenase enzymes. Proc Natl Acad Sci U S A 1993, 90(15):7240-7244.

50. Andrew PJ, Mayer B: Enzymatic function of nitric oxide synthases. Cardiovasc Res 1999, 43(3):521-531.

51. Anselm E, Chataigneau M, Ndiaye M, Chataigneau T, Schini-Kerth VB: Grape juice causes endothelium-dependent relaxation via a redox-sensitive Src- and Akt-dependent activation of eNOS. Cardiovasc Res 2007 73(2):404-413

52. Feletou M, Vanhoutte PM: EDHF: an update. Clin Sci (Lond) 2009, 117(4):139-155. 
53. Ozkor MA, Quyyumi AA: Endothelium-derived hyperpolarizing factor and vascular function. Cardiol Res Pract 2011, 2011:156146.

54. Sandow SL, Tare M, Coleman HA, Hill CE, Parkington HC: Involvement of myoendothelial gap junctions in the actions of endothelium-derived hyperpolarizing factor. Circ Res 2002, 90(10):1108-1113.

55. Doughty JM, Plane F, Langton PD: Charybdotoxin and apamin block EDHF in rat mesenteric artery if selectively applied to the endothelium. Am J Physiol 1999, 276(3 Pt 2):H1107-H1112.

56. Corriu C, Feletou M, Canet E, Vanhoutte PM: Endothelium-derived factors and hyperpolarization of the carotid artery of the guinea-pig. $\mathrm{Br} J$ Pharmacol 1996, 119(5):959-964.

57. Murphy ME, Brayden JE: Apamin-sensitive $\mathrm{K}+$ channels mediate an endothelium-dependent hyperpolarization in rabbit mesenteric arteries. J Physiol 1995, 489(Pt 3):723-734.

58. Hannah RM, Dunn KM, Bonev AD, Nelson MT: Endothelial SK(Ca) and IK (Ca) channels regulate brain parenchymal arteriolar diameter and cortical cerebral blood flow. J Cereb Blood Flow Metab 2011, 31(5):1175-1186

59. Chataigneau T, Feletou M, Duhault J, Vanhoutte PM: Epoxyeicosatrienoic acids, potassium channel blockers and endothelium-dependent hyperpolarization in the guinea-pig carotid artery. Br J Pharmacol 1998, 123(3):574-580.

60. Nelson MT, Quayle JM: Physiological roles and properties of potassium channels in arterial smooth muscle. Am J Physiol 1995, 268(4 Pt 1):C799-C822.

61. Neylon CB, Lang RJ, Fu Y, Bobik A, Reinhart PH: Molecular cloning and characterization of the intermediate-conductance $\mathrm{Ca}(2+)$-activated $\mathrm{K}(+)$ channel in vascular smooth muscle: relationship between $\mathrm{K}(\mathrm{Ca})$ channel diversity and smooth muscle cell function. Circ Res 1999, 85(9):e33-e43.

62. Larsen BT, Gutterman DD, Sato A, Toyama K, Campbell WB, Zeldin DC, Manthati VL, Falck JR, Miura H: Hydrogen peroxide inhibits cytochrome p450 epoxygenases: interaction between two endothelium-derived hyperpolarizing factors. Circ Res 2008, 102(1):59-67.

63. Yada T, Shimokawa H, Hiramatsu O, Kajita T, Shigeto F, Goto M, Ogasawara $Y$, Kajiya F: Hydrogen peroxide, an endogenous endothelium-derived hyperpolarizing factor, plays an important role in coronary autoregulation in vivo. Circulation 2003, 107(7):1040-1045.

64. Matoba T, Shimokawa H, Nakashima M, Hirakawa Y, Mukai Y, Hirano K, Kanaide $\mathrm{H}$, Takeshita A: Hydrogen peroxide is an endothelium-derived hyperpolarizing factor in mice. J Clin Invest 2000, 106(12):1521-1530.

65. Morikawa K, Shimokawa H, Matoba T, Kubota H, Akaike T, Talukder MA Hatanaka M, Fujiki T, Maeda H, Takahashi S, Takeshita A: Pivotal role of Cu, $\mathrm{Zn}$-superoxide dismutase in endothelium-dependent hyperpolarization. J Clin Invest 2003, 112(12):1871-1879.

66. Wynne BM, Labazi H, Tostes RC, Webb RC: Aorta from angiotensin II hypertensive mice exhibit preserved nitroxyl anion mediated relaxation responses. Pharmacol Res 2012, 65(1):41-47.

67. Andrews KL, Irvine JC, Tare M, Apostolopoulos J, Favaloro JL, Triggle CR, Kemp-Harper BK: A role for nitroxyl (HNO) as an endothelium-derived relaxing and hyperpolarizing factor in resistance arteries. Br J Pharmacol 2009, 157(4):540-550.

68. Mustafa AK, Sikka G, Gazi SK, Steppan J, Jung SM, Bhunia AK, Barodka VM, Gazi FK, Barrow RK, Wang R, Amzel LM, Berkowitz DE, Snyder SH: Hydrogen sulfide as endothelium-derived hyperpolarizing factor sulfhydrates potassium channels. Circ Res 2011, 109(11):1259-1268.

69. Shimokawa H, Yasutake H, Fujii K, Owada MK, Nakaike R, Fukumoto Y, Takayanagi T, Nagao T, Egashira K, Fujishima M, Takeshita A: The importance of the hyperpolarizing mechanism increases as the vessel size decreases in endothelium-dependent relaxations in rat mesenteric circulation. J Cardiovasc Pharmacol 1996, 28(5):703-711.

70. Bellien J, Joannides R, lacob M, Arnaud P, Thuillez C: Evidence for a basal release of a cytochrome-related endothelium-derived hyperpolarizing factor in the radial artery in humans. Am J Physiol Heart Circ Physiol 2006, 290(4):H1347-H1352.

71. Ozkor MA, Murrow JR, Rahman AM, Kavtaradze N, Lin J, Manatunga A, Quyyumi AA: Endothelium-derived hyperpolarizing factor determines resting and stimulated forearm vasodilator tone in health and in disease. Circulation 2011, 123(20):2244-2253.

72. Caughey GE, Cleland LG, Penglis PS, Gamble JR, James MJ: Roles of cyclooxygenase (COX)-1 and COX-2 in prostanoid production by human endothelial cells: selective up-regulation of prostacyclin synthesis by COX-2. J Immunol 2001, 167(5):2831-2838.

73. Kirkby NS, Lundberg MH, Harrington LS, Leadbeater PD, Milne GL, Potter CM, Al-Yamani M, Adeyemi O, Warner TD, Mitchell JA: Cyclooxygenase-1, not cyclooxygenase-2, is responsible for physiological production of prostacyclin in the cardiovascular system. Proc Natl Acad Sci U S A 2012, 109(43):17597-17602.

74. Ricciotti E, Yu Y, Grosser T, Fitzgerald GA: COX-2, the dominant source of prostacyclin. Proc Natl Acad Sci U S A 2013, 110(3):E183.

75. Tare M, Parkington HC, Coleman HA: EDHF, NO and a prostanoid: hyperpolarization-dependent and -independent relaxation in guinea-pig arteries. Br J Pharmacol 2000, 130(3):605-618.

76. Dautzenberg M, Just A: Temporal characteristics of nitric oxideprostaglandin-, and EDHF-mediated components of endotheliumdependent vasodilation in the kidney. Am J Physiol Regul Integr Comp Physiol 2013, 305(9):R987-R998.

77. Li X, Fang P, Mai J, Choi ET, Wang H, Yang XF: Targeting mitochondrial reactive oxygen species as novel therapy for inflammatory diseases and cancers. J Hematol Oncol 2013, 6:19.

78. Addabbo F, Montagnani M, Goligorsky MS: Mitochondria and reactive oxygen species. Hypertension 2009, 53(6):885-892.

79. Zhang JG, Nicholls-Grzemski FA, Tirmenstein MA, Fariss MW: Vitamin E succinate protects hepatocytes against the toxic effect of reactive oxygen species generated at mitochondrial complexes I and III by alkylating agents. Chem Biol Interact 2001, 138(3):267-284.

80. Yang B, Rizzo V: TNF-alpha potentiates protein-tyrosine nitration through activation of NADPH oxidase and eNOS localized in membrane rafts and caveolae of bovine aortic endothelial cells. Am J Physiol Heart Circ Physiol 2007, 292(2):H954-H962.

81. Cai $\mathrm{H}: \mathrm{NAD}(\mathrm{P}) \mathrm{H}$ oxidase-dependent self-propagation of hydrogen peroxide and vascular disease. Circ Res 2005, 96(8):818-822.

82. Houstis N, Rosen ED, Lander ES: Reactive oxygen species have a causal role in multiple forms of insulin resistance. Nature 2006, 440(7086):944-948

83. Mugge A, Elwell JH, Peterson TE, Hofmeyer TG, Heistad DD, Harrison DG: Chronic treatment with polyethylene-glycolated superoxide dismutase partially restores endothelium-dependent vascular relaxations in cholesterol-fed rabbits. Circ Res 1991, 69(5):1293-1300.

84. Miller FJ Jr, Gutterman DD, Rios CD, Heistad DD, Davidson BL: Superoxide production in vascular smooth muscle contributes to oxidative stress and impaired relaxation in atherosclerosis. Circ Res 1998, 82(12):1298-1305.

85. Langenstroer P, Pieper GM: Regulation of spontaneous EDRF release in diabetic rat aorta by oxygen free radicals. Am J Physiol 1992, 263(1 Pt 2):H257-H265.

86. Oak JH, Cai H: Attenuation of angiotensin II signaling recouples eNOS and inhibits nonendothelial NOX activity in diabetic mice. Diabetes 2007, 56(1):118-126.

87. Bulua AC, Simon A, Maddipati R, Pelletier M, Park H, Kim KY, Sack MN, Kastner DL, Siegel RM: Mitochondrial reactive oxygen species promote production of proinflammatory cytokines and are elevated in TNFR1associated periodic syndrome (TRAPS). J Exp Med 2011, 208(3):519-533.

88. David F, Farley J, Huang H, Lavoie JP, Laverty S: Cytokine and chemokine gene expression of IL-1 beta stimulated equine articular chondrocytes. Vet Surg 2007, 36(3):221-227.

89. Vlahopoulos S, Boldogh I, Casola A, Brasier AR: Nuclear factor-kappaBdependent induction of interleukin-8 gene expression by tumor necrosis factor alpha: evidence for an antioxidant sensitive activating pathway distinct from nuclear translocation. Blood 1999, 94(6):1878-1889.

90. Zhang C: The role of inflammatory cytokines in endothelial dysfunction. Basic Res Cardiol 2008, 103(5):398-406

91. Bagnost T, Berthelot A, Bouhaddi M, Laurant P, Andre C, Guillaume Y, Demougeot C: Treatment with the arginase inhibitor N(omega)-hydroxynor-L-arginine improves vascular function and lowers blood pressure in adult spontaneously hypertensive rat. J Hypertens 2008, 26(6):1110-1118.

92. Demougeot C, Prigent-Tessier A, Marie C, Berthelot A: Arginase inhibition reduces endothelial dysfunction and blood pressure rising in spontaneously hypertensive rats. J Hypertens 2005, 23(5):971-978.

93. Toque HA, Romero MJ, Tostes RC, Shatanawi A, Chandra S, Carneiro ZN, Inscho EW, Webb RC, Caldwell RB, Caldwell RW: p38 Mitogen-activated protein kinase (MAPK) increases arginase activity and contributes to 
endothelial dysfunction in corpora cavernosa from angiotensin-II-treated mice. J Sex Med 2010, 7(12):3857-3867.

94. Satoh M, Fujimoto S, Arakawa S, Yada T, Namikoshi T, Haruna Y, Horike H, Sasaki T, Kashihara N: Angiotensin II type 1 receptor blocker ameliorates uncoupled endothelial nitric oxide synthase in rats with experimental diabetic nephropathy. Nephrol Dial Transplant 2008, 23(12):3806-3813.

95. Virdis A, Colucci R, Neves MF, Rugani I, Aydinoglu F, Fornai M, Ippolito C, Antonioli L, Duranti E, Solini A, Bernardini N, Blandizzi C, Taddei S: Resistance artery mechanics and composition in angiotensin Il-infused mice: effects of cyclooxygenase-1 inhibition. Eur Heart J 2012, 33(17):2225-2234

96. Cheng ZJ, Vapaatalo H, Mervaala E: Angiotensin II and vascular inflammation. Med Sci Monit 2005, 11(6):RA194-RA205.

97. Kourembanas S, McQuillan LP, Leung GK, Faller DV: Nitric oxide regulates the expression of vasoconstrictors and growth factors by vascular endothelium under both normoxia and hypoxia. J Clin Invest 1993, 92(1):99-104.

98. Wiley KE, Davenport AP: Nitric oxide-mediated modulation of the endothelin-1 signalling pathway in the human cardiovascular system. Br J Pharmacol 2001, 132(1):213-220.

99. Minshall RD, Sessa WC, Stan RV, Anderson RG, Malik AB: Caveolin regulation of endothelial function. Am J Physiol Lung Cell Mol Physiol 2003, 285(6):L1179-L1183.

100. Amiri F, Virdis A, Neves MF, Iglarz M, Seidah NG, Touyz RM, Reudelhuber TL, Schiffrin EL: Endothelium-restricted overexpression of human endothelin-1 causes vascular remodeling and endothelial dysfunction. Circulation 2004, 110(15):2233-2240.

101. Amiri F, Ko EA, Javeshghani D, Reudelhuber TL, Schiffrin EL: Deleterious combined effects of salt-loading and endothelial cell restricted endothelin-1 overexpression on blood pressure and vascular function in mice. J Hypertens 2010, 28(6):1243-1251.

102. Javeshghani D, Barhoumi T, Idris-Khodja N, Paradis P, Schiffrin EL: Reduced macrophage-dependent inflammation improves endothelin-1-induced vascular injury. Hypertension 2013, 62(1):112-117.

103. De Ciuceis C, Amiri F, Brassard P, Endemann DH, Touyz RM, Schiffrin EL: Reduced vascular remodeling, endothelial dysfunction, and oxidative stress in resistance arteries of angiotensin II-infused macrophage colonystimulating factor-deficient mice: evidence for a role in inflammation in angiotensin-induced vascular injury. Arterioscler Thromb Vasc Biol 2005, 25(10):2106-2113.

104. Barhoumi T, Kasal DA, Li MW, Shbat L, Laurant P, Neves MF, Paradis $P$, Schiffrin EL: T regulatory lymphocytes prevent angiotensin II-induced hypertension and vascular injury. Hypertension 2011, 57(3):469-476.

105. Bhagat $K$, Vallance P: Inflammatory cytokines impair endotheliumdependent dilatation in human veins in vivo. Circulation 1997, 96(9):3042-3047.

106. Stenvinkel P: Endothelial dysfunction and inflammation-is there a link? Nephrol Dial Transplant 2001, 16(10):1968-1971.

107. Herder C, Carstensen M, Ouwens DM: Anti-inflammatory cytokines and risk of type 2 diabetes. Diabetes Obes Metab 2013, 15(Suppl 3):39-50.

108. Gleissner CA, Zastrow A, Klingenberg R, Kluger MS, Konstandin M, Celik S, Haemmerling S, Shankar V, Giese T, Katus HA, Dengler TJ: IL-10 inhibits endothelium-dependent $\mathrm{T}$ cell costimulation by up-regulation of ILT3/4 in human vascular endothelial cells. Eur J Immunol 2007, 37(1):177-192

109. Moore KW, de Waal MR, Coffman RL, O'Garra A: Interleukin-10 and the interleukin-10 receptor. Annu Rev Immunol 2001, 19:683-765.

110. Caligiuri G, Rudling M, Ollivier V, Jacob MP, Michel JB, Hansson GK, Nicoletti A: Interleukin-10 deficiency increases atherosclerosis, thrombosis, and low-density lipoproteins in apolipoprotein E knockout mice. Mol Med 2003, 9(1-2):10-17.

111. Gunnett CA, Heistad DD, Faraci FM: Interleukin-10 protects nitric oxidedependent relaxation during diabetes: role of superoxide. Diabetes 2002 51(6):1931-1937.

112. Didion SP, Kinzenbaw DA, Schrader LI, Chu Y, Faraci FM: Endogenous interleukin-10 inhibits angiotensin II-induced vascular dysfunction. Hypertension 2009, 54(3):619-624.

113. Oberholzer A, Oberholzer C, Moldawer LL: Interleukin-10: a complex role in the pathogenesis of sepsis syndromes and its potential as an anti-inflammatory drug. Crit Care Med 2002, 30(1 Supp):S58-S63.
114. Gunnett CA, Heistad DD, Berg DJ, Faraci FM: IL-10 deficiency increases superoxide and endothelial dysfunction during inflammation. Am J Physiol Heart Circ Physiol 2000, 279(4):H1555-H1562.

115. Haddad JJ, Fahlman CS: Redox- and oxidant-mediated regulation of interleukin-10: an anti-inflammatory, antioxidant cytokine? Biochem Biophys Res Commun 2002, 297(2):163-176.

116. Fichtlscherer S, Breuer S, Heeschen C, Dimmeler S, Zeiher AM: Interleukin-10 serum levels and systemic endothelial vasoreactivity in patients with coronary artery disease. J Am Coll Cardiol 2004, 44(1):44-49.

117. Dang PM, Elbim C, Marie JC, Chiandotto M, Gougerot-Pocidalo MA, ElBenna J: Anti-inflammatory effect of interleukin-10 on human neutrophil respiratory burst involves inhibition of GM-CSF-induced p47PHOX phosphorylation through a decrease in ERK1/2 activity. FASEB J 2006, 20(9):1504-1506.

118. Zemse SM, Hilgers RH, Webb RC: Interleukin-10 counteracts impaired endothelium-dependent relaxation induced by ANG II in murine aortic rings. Am J Physiol Heart Circ Physiol 2007, 292(6):H3103-H3108.

119. Kassan M, Galan M, Partyka M, Trebak M, Matrougui K: Interleukin-10 released by $\mathrm{CD} 4(+) \mathrm{CD} 25(+)$ natural regulatory $\mathrm{T}$ cells improves microvascular endothelial function through inhibition of NADPH oxidase activity in hypertensive mice. Arterioscler Thromb Vasc Biol 2011, 31(11):2534-2542.

120. Kinzenbaw DA, Chu Y, Pena Silva RA, Didion SP, Faraci FM: Interleukin-10 protects against aging-induced endothelial dysfunction. Physiol Rep 2013, 1(6):e00149.

121. Sikka G, Miller KL, Steppan J, Pandey D, Jung SM, Fraser CD 3rd, Ellis C, Ross D, Vandegaer K, Bedja D, Gabrielson K, Walston JD, Berkowitz DE, Barouch LA: Interleukin 10 knockout frail mice develop cardiac and vascular dysfunction with increased age. Exp Geronto/ 2013, 48(2):128-135.

122. Fiorentino DF, Zlotnik A, Mosmann TR, Howard M, O'Garra A: IL-10 inhibits cytokine production by activated macrophages. J Immunol 1991, 147(11):3815-3822

123. Fiorentino DF, Zlotnik A, Vieira P, Mosmann TR, Howard M, Moore KW, O'Garra A: IL-10 acts on the antigen-presenting cell to inhibit cytokine production by Th1 cells. J Immunol 1991, 146(10):3444-3451.

124. de Waal MR, Abrams J, Bennett B, Figdor CG, de Vries JE: Interleukin 10(IL10) inhibits cytokine synthesis by human monocytes: an autoregulatory role of IL-10 produced by monocytes. J Exp Med 1991, 174(5):1209-1220.

125. Asadullah K, Sterry W, Volk HD: Interleukin-10 therapy-review of a new approach. Pharmacol Rev 2003, 55(2):241-269.

126. Csiszar A, Wang M, Lakatta EG, Ungvari Z: Inflammation and endothelial dysfunction during aging: role of NF-kappaB. J Appl Physiol (1985) 2008, 105(4):1333-1341.

127. Marchesi C, Paradis $P$, Schiffrin EL: Role of the renin-angiotensin system in vascular inflammation. Trends Pharmacol Sci 2008, 29(7):367-374.

128. Huang X, Gong R, Li X, Virtue A, Yang F, Yang $H_{\text {, }}$ Tran AH, Yang XF, Wang $\mathrm{H}$ : Identification of novel pretranslational regulatory mechanisms for NF-kappaB activation. J Biol Chem 2013, 288(22):15628-15640.

129. Seitz M, Loetscher P, Dewald B, Towbin H, Gallati H, Baggiolini M: Interleukin-10 differentially regulates cytokine inhibitor and chemokine release from blood mononuclear cells and fibroblasts. Eur J Immunol 1995, 25(4):1129-1132.

130. Zemse SM, Chiao CW, Hilgers RH, Webb RC: Interleukin-10 inhibits the in vivo and in vitro adverse effects of TNF-alpha on the endothelium of murine aorta. Am J Physiol Heart Circ Physiol 2010, 299(4):H1160-H1167.

131. Riley JK, Takeda K, Akira S, Schreiber RD: Interleukin-10 receptor signaling through the JAK-STAT pathway. Requirement for two distinct receptor-derived signals for anti-inflammatory action. J Biol Chem 1999, 274(23):16513-16521

132. Cattaruzza M, Slodowski W, Stojakovic M, Krzesz R, Hecker M: Interleukin-10 induction of nitric-oxide synthase expression attenuates CD40-mediated interleukin-12 synthesis in human endothelial cells. J Biol Chem 2003, 278(39):37874-37880.

133. Wehinger J, Gouilleux F, Groner B, Finke J, Mertelsmann R, Weber-Nordt RM: $\mathrm{IL}-10$ induces DNA binding activity of three STAT proteins (Stat1, Stat3, and Stat5) and their distinct combinatorial assembly in the promoters of selected genes. FEBS Lett 1996, 394(3):365-370.

134. Finbloom DS, Winestock KD: IL-10 induces the tyrosine phosphorylation of tyk2 and Jak1 and the differential assembly of STAT1 alpha and STAT3 complexes in human T cells and monocytes. J Immunol 1995, 155(3):1079-1090. 
135. Pattison MJ, Mackenzie KF, Arthur JS: Inhibition of JAKs in macrophages increases lipopolysaccharide-induced cytokine production by blocking IL-10-mediated feedback. J Immunol 2012, 189(6):2784-2792.

136. Jojima T, Suzuki K, Hirama N, Uchida K, Hattori Y: Glimepiride upregulates eNOS activity and inhibits cytokine-induced NF-kappaB activation through a phosphoinoside 3-kinase-Akt-dependent pathway. Diabetes Obes Metab 2009, 11(2):143-149.

137. D'Angelo G, Adam LP: Inhibition of ERK attenuates force development by lowering myosin light chain phosphorylation. Am J Physiol Heart Circ Physiol 2002, 282(2):H602-H610.

138. Stumpf C, Lehner C, Yilmaz A, Daniel WG, Garlichs CD: Decrease of serum levels of the anti-inflammatory cytokine interleukin-10 in patients with advanced chronic heart failure. Clin Sci (Lond) 2003, 105(1):45-50.

139. Suttles J, Milhorn DM, Miller RW, Poe JC, Wahl LM, Stout RD: CD40 signaling of monocyte inflammatory cytokine synthesis through an ERK1/2-dependent pathway. A target of interleukin (il)-4 and il-10 anti-inflammatory action. J Biol Chem 1999, 274(9):5835-5842.

140. Giachini FR, Zemse SM, Carneiro FS, Lima W, Carneiro ZN, Callera GE, Ergu A, Webb RC, Tostes RC: Interleukin-10 attenuates vascular responses to endothelin-1 via effects on ERK1/2-dependent pathway. Am J Physiol Heart Circ Physiol 2009, 296(2):H489-H496.

141. Noh KT, Son KH, Jung ID, Kang HK, Hwang SA, Lee WS, You JC, Park YM: Protein kinase $C$ delta (PKCdelta)-extracellular signal-regulated kinase $1 / 2$ (ERK1/2) signaling cascade regulates glycogen synthase kinase-3 (GSK-3) inhibition-mediated interleukin-10 (IL-10) expression in lipopolysaccharide (LPS)-induced endotoxemia. J Biol Chem 2012, 287(17):14226-14233.

142. Williams L, Bradley L, Smith A, Foxwell B: Signal transducer and activator of transcription 3 is the dominant mediator of the anti-inflammatory effects of IL-10 in human macrophages. J Immunol 2004, 172(1):567-576.

143. Lang R, Patel D, Morris JJ, Rutschman RL, Murray PJ: Shaping gene expression in activated and resting primary macrophages by IL-10. $\mathrm{J}$ Immunol 2002, 169(5):2253-2263.

144. Antoniv TT, Ivashkiv LB: Interleukin-10-induced gene expression and suppressive function are selectively modulated by the PI3K-Akt-GSK3 pathway. Immunology 2011, 132(4):567-577.

145. Pepper MS: Transforming growth factor-beta: vasculogenesis, angiogenesis, and vessel wall integrity. Cytokine Growth Factor Rev 1997, 8(1):21-43.

146. Massague J: The transforming growth factor-beta family. Annu Rev Cell Biol 1990, 6:597-641.

147. Roberts AB: Molecular and cell biology of TGF-beta. Miner Electrolyte Metab 1998, 24(2-3):111-119.

148. Morello JP, Plamondon J, Meyrick B, Hoover R, O'Connor-McCourt MD: Transforming growth factor-beta receptor expression on endothelial cells: heterogeneity of type III receptor expression. J Cell Physiol 1995, 165(1):201-211.

149. Saura M, Zaragoza C, Cao W, Bao C, Rodriguez-Puyol M, Rodriguez-Puyol D, Lowenstein CJ: Smad2 mediates transforming growth factor-beta induction of endothelial nitric oxide synthase expression. Circ Res 2002, 91(9):806-813.

150. Vasquez R, Farias M, Vega JL, Martin RS, Vecchiola A, Casanello P, Sobrevia L: $\mathrm{D}$-glucose stimulation of L-arginine transport and nitric oxide synthesis results from activation of mitogen-activated protein kinases p42/44 and Smad2 requiring functional type II TGF-beta receptors in human umbilical vein endothelium. J Cell Physio/ 2007, 212(3):626-632.

151. Kehrl JH, Wakefield LM, Roberts AB, Jakowlew S, Alvarez-Mon M, Derynck R, Sporn MB, Fauci AS: Production of transforming growth factor beta by human $\mathrm{T}$ lymphocytes and its potential role in the regulation of $\mathrm{T}$ cell growth. J Exp Med 1986, 163(5):1037-1050.

152. Saura M, Zaragoza C, Herranz B, Griera M, Diez-Marques L, Rodriguez-Puyol D, Rodriguez-Puyol M: Nitric oxide regulates transforming growth factor-beta signaling in endothelial cells. Circ Res 2005, 97(11):1115-1123.

153. Walshe TE, dela Paz NG, D'Amore PA: The role of shear-induced transforming growth factor-beta signaling in the endothelium. Arterioscler Thromb Vasc Biol 2013, 33(11):2608-2617.

154. Ying WZ, Aaron KJ, Sanders PW: Transforming growth factor-beta regulates endothelial function during high salt intake in rats. Hypertension 2013, 62(5):951-956.

155. Letterio JJ, Roberts AB: Regulation of immune responses by TGF-beta. Annu Rev Immunol 1998, 16:137-161.
156. Li MO, Wan YY, Flavell RA: T cell-produced transforming growth factor-beta1 controls $T$ cell tolerance and regulates Th1- and Th17-cell differentiation. Immunity 2007, 26(5):579-591.

157. Pastrana JL, Sha X, Virtue A, Mai J, Cueto R, Lee IA, Wang H, Yang XF: Regulatory T cells and Atherosclerosis. J Clin Exp Cardiolog 2012, 2012(Suppl 12):2.

158. Nold MF, Nold-Petry CA, Zepp JA, Palmer BE, Bufler P, Dinarello CA: IL-37 is a fundamental inhibitor of innate immunity. Nat Immunol 2010, 11(11):1014-1022.

159. Miller AM: Role of IL-33 in inflammation and disease. J Inflamm (Lond) 2011, 8(1):22.

160. Miller AM, Xu D, Asquith DL, Denby L, Li Y, Sattar N, Baker AH, Mclnnes IB, Liew FY: IL-33 reduces the development of atherosclerosis. J Exp Med 2008, 205(2):339-346.

161. Miller AM, Asquith DL, Hueber AJ, Anderson LA, Holmes WM, McKenzie AN, Xu D, Sattar N, McInnes IB, Liew FY: Interleukin-33 induces protective effects in adipose tissue inflammation during obesity in mice. Circ Res 2010, 107(5):650-658.

162. Moussion C, Ortega N, Girard JP: The IL-1-like cytokine IL-33 is constitutively expressed in the nucleus of endothelial cells and epithelial cells in vivo: a novel 'alarmin'? PLoS One 2008, 3(10):e3331.

163. Grehan JF, Levay-Young BK, Fogelson JL, Francois-Bongarcon V, Benson BA, Dalmasso AP: IL-4 and IL-13 induce protection of porcine endothelial cells from killing by human complement and from apoptosis through activation of a phosphatidylinositide 3-kinase/Akt pathway. J Immunol 2005, 175(3):1903-1910.

164. Dalmasso AP, Goldish D, Benson BA, Tsai AK, Wasiluk KR, Vercellotti GM: Interleukin-4 induces up-regulation of endothelial cell claudin-5 through activation of FoxO1: role in protection from complement-mediated injury. J Biol Chem 2014, 289(2):838-847

165. Collison LW, Workman CJ, Kuo TT, Boyd K, Wang Y, Vignali KM, Cross R, Sehy D, Blumberg RS, Vignali DA: The inhibitory cytokine IL-35 contributes to regulatory T-cell function. Nature 2007, 450(7169):566-569.

166. Wang RX, Yu CR, Dambuza IM, Mahdi RM, Dolinska MB, Sergeev YV, Wingfield PT, Kim SH, Egwuagu CE: Interleukin-35 induces regulatory B cells that suppress autoimmune disease. Nat Med 2014, 20(6):633-641.

167. Shen $P$, Roch $T$, Lampropoulou V, O'Connor RA, Stervbo U, Hilgenberg $E$, Ries S, Dang VD, Jaimes Y, Daridon C, Li R, Jouneau L, Boudinot P, Wilantri S, Sakwa I, Miyazaki Y, Leech MD, McPherson RC, Wirtz S, Neurath M, Hoehlig K, Meinl E, Grützkau A, Grün JR, Horn K, Kühl AA, Dörner T, Bar-Or A, Kaufmann SH, Anderton SM, et al: IL-35-producing B cells are critical regulators of immunity during autoimmune and infectious diseases. Nature 2014, 507(7492):366-370

168. Li X, Mai J, Virtue A, Yin Y, Gong R, Sha X, Gutchigian S, Frisch A, Hodge I, Jiang $X$, Wang H, Yang XF: IL-35 is a novel responsive anti-inflammatory cytokine-a new system of categorizing anti-inflammatory cytokines. PLoS One 2012, 7(3):e33628.

169. Virtue $A$, Wang $H$, Yang XF: MicroRNAs and toll-like receptor/interleukin-1 receptor signaling. J Hematol Oncol 2012, 5:66.

170. Virtue A, Mai J, Yin Y, Meng S, Tran T, Jiang X, Wang H, Yang XF: Structural evidence of anti-atherogenic microRNAs. Front Biosci (Landmark Ed) 2011 16:3133-3145

171. Taganov KD, Boldin MP, Chang KJ, Baltimore D: NF-kappaB-dependent induction of microRNA miR-146, an inhibitor targeted to signaling proteins of innate immune responses. Proc Natl Acad Sci U S A 2006, 103(33):12481-12486

172. Bhaumik D, Patil CK, Campisi J: MicroRNAs: an important player in maintaining a balance between inflammation and tumor suppression. Cell Cycle 2009, 8(12):1822.

173. Perry MM, Moschos SA, Williams AE, Shepherd NJ, Larner-Svensson HM, Lindsay MA: Rapid changes in microRNA-146a expression negatively regulate the IL-1beta-induced inflammatory response in human lung alveolar epithelial cells. J Immuno/ 2008, 180(8):5689-5698.

174. Xiao B, Liu Z, Li BS, Tang B, Li W, Guo G, Shi Y, Wang F, Wu Y, Tong WD, Guo H, Mao XH, Zou QM: Induction of microRNA-155 during Helicobacter pylori infection and its negative regulatory role in the inflammatory response. J Infect Dis 2009, 200(6):916-925.

175. Worm J, Stenvang J, Petri A, Frederiksen KS, Obad S, Elmen J, Hedtjarn M, Straarup EM, Hansen JB, Kauppinen S: Silencing of microRNA-155 in mice during acute inflammatory response leads to derepression of c/ebp 
Beta and down-regulation of G-CSF. Nucleic Acids Res 2009, 37(17):5784-5792.

176. Matsui J, Wakabayashi T, Asada M, Yoshimatsu K, Okada M: Stem cell factor/c-kit signaling promotes the survival, migration, and capillary tube formation of human umbilical vein endothelial cells. J Biol Chem 2004, 279(18):18600-18607.

177. Suarez Y, Wang C, Manes TD, Pober JS: Cutting edge: TNF-induced microRNAs regulate TNF-induced expression of E-selectin and intercellular adhesion molecule-1 on human endothelial cells: feedback control of inflammation. J Immunol 2010, 184(1):21-25.

178. Harris TA, Yamakuchi M, Ferlito M, Mendell JT, Lowenstein CJ: MicroRNA-126 regulates endothelial expression of vascular cell adhesion molecule 1. Proc Natl Acad Sci U S A 2008, 105(5):1516-1521.

179. Sun X, Icli B, Wara AK, Belkin N, He S, Kobzik L, Hunninghake GM, Vera MP, Blackwell TS, Baron RM, Feinberg MW: MicroRNA-181b regulates NF-kappaB-mediated vascular inflammation. J Clin Invest 2012, 122(6):1973-1990.

180. Fang Y, Shi C, Manduchi E, Civelek M, Davies PF: MicroRNA-10a regulation of proinflammatory phenotype in athero-susceptible endothelium in vivo and in vitro. Proc Natl Acad Sci U S A 2010, 107(30):13450-13455.

181. Suarez Y, Fernandez-Hernando C, Pober JS, Sessa WC: Dicer dependent microRNAs regulate gene expression and functions in human endothelial cells. Circ Res 2007, 100(8):1164-1173.

182. Hagiwara S, McClelland A, Kantharidis P: MicroRNA in Diabetic Nephropathy: Renin Angiotensin, AGE/RAGE, and Oxidative Stress Pathway. J Diabetes Res 2013, 2013:173783.

183. Sun HX, Zeng DY, Li RT, Pang RP, Yang H, Hu YL, Zhang Q, Jiang Y, Huang $L Y$, Tang YB, Yan GJ, Zhou JG: Essential role of microRNA-155 in regulating endothelium-dependent vasorelaxation by targeting endothelial nitric oxide synthase. Hypertension 2012, 60(6):1407-1414.

184. Li D, Yang P, Xiong Q, Song X, Yang X, Liu L, Yuan W, Rui YC: MicroRNA$125 \mathrm{a} / \mathrm{b}-5 \mathrm{p}$ inhibits endothelin-1 expression in vascular endothelial cells. J Hypertens 2010, 28(8):1646-1654.

doi:10.1186/s13045-014-0080-6

Cite this article as: Shao et al:: Immunosuppressive/anti-inflammatory cytokines directly and indirectly inhibit endothelial dysfunction- a novel mechanism for maintaining vascular function. Journal of Hematology \& Oncology 2014 7:80.

\section{Submit your next manuscript to BioMed Central and take full advantage of:}

- Convenient online submission

- Thorough peer review

- No space constraints or color figure charges

- Immediate publication on acceptance

- Inclusion in PubMed, CAS, Scopus and Google Scholar

- Research which is freely available for redistribution 